\title{
Teachers' Interactions and their Collaborative Reflection Processes during Peer Meetings
}

\author{
DINEKE E.H. TIGELAAR ${ }^{1, *}$, DIANA H.J.M. DOLMANS ${ }^{2}$, \\ PAULIEN C. MEIJER ${ }^{1}$, WILLEM S. DE GRAVE ${ }^{2}$, and \\ CEES P.M. VAN DER VLEUTEN ${ }^{2}$ \\ ${ }^{1}$ Graduate School of Teaching, Leiden University, PO BOX 9555, 2300 RB, Leiden, The \\ Netherlands; ${ }^{2}$ Department of Educational Research \& Development, Medical School, Maastricht \\ University, Maastricht, The Netherlands (*author for correspondence, Phone: +31-71-5273498; \\ Fax: +31-71-5275342; E-mail: DTigelaar@iclon.leidenuniv.nl)
}

(Received: 7 July 2006; Accepted: 20 September 2006)

\begin{abstract}
Teachers' reflections are often narrowly focused on technical questions ('how to') and less on the underlying moral, political and emotional aspects of their functioning. However, for a better understanding of teaching practice it is important to uncover beliefs and values that usually remain implicit. Meeting with others is considered crucial for enhancing the quality of teachers' reflections. However, little is known about how any beneficial effects of such meetings are brought about. We explored the relationship between medical teachers' interactions and collaborative reflection processes during peer meetings. Five experienced teachers and a teacher trainer participated in the study. Three peer meetings were videotaped and transcribed. Teachers' interactions and collaborative reflective processes were analysed. The interactions promoted reflection not only on technical questions but also on moral, political, and emotional issues. 'Guiding/directing', 'proposing an alternative' and 'exploring an alternative' appeared to be the principal interactions. The results may be useful for teachers and trainers who are considering organising and/or improving peer meetings.
\end{abstract}

Key words: collaborative reflection, critical incidents, interactions, meetings, peer, teacher development

\section{Introduction}

Like all professionals, teachers should continue to develop professionally throughout their career paths. Learning from experience is crucial to this process (Eraut, 1994). Whilst beginning medical teachers learn the most by observing and practising skills, experienced teachers improve mainly by reflecting on their teaching and discussing teaching issues with colleagues (Jung et al., 2005; MacDougall and Drummond, 2005). These findings are in line with the concept of teaching as a social practice (D' Eon et al., 2000). It is widely acknowledged that reflection is a prerequisite for in depth understanding of teaching and for furthering teachers' professional development. Whether 
reflection actually leads to deeper understanding depends on the extent to which it addresses implicit beliefs and values that underpin teachers' functioning (Gilroy, 1993; Eraut, 1994). Exchanging experiences and ideas with others is considered essential for enhancing quality of reflection (Hatton and Smith, 1995; Bereiter, 2002). Meeting with colleagues is a popular way of sharing experiences and ideas (Ackland, 1991; Joyce and Showers, 1995; Gallacher, 1997; Thijs and Van den Berg, 2002). Such peer meetings allow participants to talk about and improve their teaching. In peer meetings, teachers review their teaching experiences with a view to improving or gaining insight into their teaching practice (Meijer, 2005). Additionally, teachers train their conversation skills, thus enhancing their professional development.

Medical teachers only rarely have opportunities to meet with peer teachers (MacDougall and Drummond, 2005). Little is known about how peer meetings stimulate teachers to reflect. That is why it seems useful to examine teachers' communication processes during such meetings. We explored medical teachers' interactions during peer meetings and how these are related to collaborative reflection processes. The results of this study are expected to be useful for teachers and teacher trainers who wish to derive greater benefit from peer meetings.

\section{THEORETICAL FRAMEWORK}

Several studies have examined teachers' interactions by analysing conversation processes during group discussions. Recently, Meijer (2005) studied beginning teachers' interactions during peer meetings. She developed a coding scheme to categorise these interactions, based on Fisher et al. (2002), Korthagen et al. (2002) and Koning (1995). The scheme contains different types of interaction, such as questioning, interpreting, summarising, proposing alternatives, etc. Meijer found that follow up questioning, clarification, interpretation, and judging a situation were important for recalling and describing situations. Student teachers identified essential aspects of situations by explaining, summarising, concretising, interpreting, guiding/ directing and giving information. Alternatives were developed and selected by asking, proposing, reacting, exploring and judging alternatives, and selecting/ agreeing on a solution. However, the interaction types occurred in different ways and there appeared to be a link between conversation topics and the way student teachers talked about them. For example, when they discussed teaching responsibilities, the student teachers focused very strongly on interactions related to formulating essential aspects, whereas the interaction during conversations about pupils or school contexts tended to focus on developing alternatives. Meijer's coding scheme appeared to be a useful tool for gaining insight into how teachers communicate during peer meetings. However, the study did not address the quality of collaborative reflection processes. 
Recently, several models were developed to investigate the quality of reflection by teachers. According to Kelchtermans and Hamilton (2004), the focus of reflection is generally on technical aspects of the acquisition of knowledge and skills. This puts 'how' questions at the centre of attention, such as 'How can I modify my teaching so as to make it more effective?' The emphasis on 'how questions' may be due to the formal nature of models that are used to stimulate reflection (Kelchtermans and Hamilton, 2004). The widely used ALACT-model, (Korthagen, 2001) for example, has proved very useful, because of its emphasis on the perspectives of others, for instance students, and for its focus on feelings in addition to behaviour. However, the stages of teachers' reflection processes are presented in a fixed order and the final focus is on formulating alternatives, which might favour an exclusively technical focus. Kelchtermans and Hamilton (2004) proposed a framework consisting of four integrated dimensions of teaching; the technical-instrumental, moral, political and emotional dimensions. The technical-instrumental dimension focuses on the 'how question' and, as we have shown, this is the dimension that is most frequently addressed by teachers. The other three dimensions, which provide underpinnings for the technical-instrumental dimension, generally receive less attention in analyses of teaching. The moral dimension refers to questions about normative beliefs about good teaching, justice and responsibility, asking such questions as 'What is the best thing that I as a teacher can do for my students?' Moral issues may conceal issues of power and interests, which are addressed in the political dimension. Central in this dimension are questions about who benefits from what teachers do? Who in the end determines what is to be taught and how? Finally, there is an emotional dimension to teaching, which, according to Kelchtermans and Hamilton (2004), plays a central role, since personal commitment and involvement are crucial for teaching. Both positive and negative emotions are important for teachers' activities. Stress and frustration, passion and satisfaction are issues that are included in this dimension of teaching.

Another framework of the quality of teachers' reflections was introduced by Korthagen (2004). According to Korthagen (2004), reflection is often limited to the surface level of behaviours and competencies. He argues that reflection should also focus on more implicit levels of teacher functioning, such as beliefs, professional identity and mission. This is depicted in a six level framework of teacher functioning. In addition to aspects that are generally accepted as relevant components of the teaching context, such as the environment, behaviours or performance and competencies, other, less explicit aspects of teacher functioning have been incorporated into the model, such as beliefs, professional identity and mission. Beliefs relate to teachers' perceptions and ideas about students, learning, etc; professional identity refers to teachers' approach to teaching, their self-concepts and, more specifically, how they 
perceive themselves as teachers and the role of the teacher in general. Finally, mission is concerned with the aims and goals that teachers pursue.

These recently developed frameworks for reflection are in line with a focus on teaching "from within", based on the idea that good teaching cannot be reduced to techniques since good teaching comes from the identity and integrity of the teacher (Palmer, 1998).

In our opinion, Kelchtermans and Hamilton's (2004) teaching dimensions cover Korthagens' model (2004). The 'how questions' in the technicalinstrumental dimension are focused on behaviours and competencies, and the other dimensions address the more implicit levels of teacher functioning, such as beliefs, professional identity and mission. Moreover, in the political dimension in particular, Kelchtermans and Hamilton place more emphasis on relationships with others than does Korthagen.

In the literature, different terms are used for quality of reflection. Reflection can remain on the surface, focusing narrowly on 'how questions' and the outer levels of functioning, such as behaviours and competencies. Reflection can also go deeper, broadening to moral, political, and emotional aspects of functioning and focusing also on inner, underlying levels of functioning, such as beliefs, identity, and mission. In this study, we use the term 'scope' of reflections with reference to Kelchtermans and Hamilton's (2004) framework. We assume that widening the scope of reflections by considering the moral, political, and emotional aspects of teaching will promote consideration of beliefs and values underpinning technical-instrumental questions. Reflections on these issues, which often remain implicit, is considered important for achieving a better understanding of teaching and for stimulating improvement (Gilroy, 1993; Eraut, 1994).

The core issue addressed in this study is: how are medical teachers' interactions during peer meetings related to the scope of their collaborative reflection processes? We used Meijer's (2005) interaction types to analyse teachers' communication processes and Kelchtermans and Hamilton's framework to analyse the scope of collaborative reflections. The following research questions were addressed: What types of interactions occur when medical teachers meet as peers? What is the scope of collaborative reflection processes during these peer meetings in terms of the teaching dimensions addressed? How are the interaction types related to the scope of collaborative reflections in terms of the teaching dimensions addressed during the peer meetings?

\section{Methods}

CONTEXT OF THE STUDY

A group of teachers from Maastricht Medical School met three times to discuss critical incidents they had encountered in their work in order to better 
understand and improve their teaching practice. The peer meetings were part of a professional development project for faculty members aspiring to a career in teaching.

\section{PARTICIPANTS}

Five experienced teachers, all medical doctors, participated in the study. They were selected by the chair of the Department of Educational Development and Research and the scientific director of the Institute for Medical Education using the criteria: proven interest in teaching as shown by participation in various teaching activities; willingness to develop as a teacher and the wish to pursue a career in teaching. An experienced teacher trainer participated in the study as well.

\section{Procedure}

Three peer meetings were arranged with a frequency of one meeting every 2 months. All five teachers participated in the meetings in the presence of a teacher trainer. The Incident method was used to structure the meetings (Hendriksen, 1997) (Table I). This method involves consideration by teachers of teaching experiences, such as problematic or challenging critical incidents. The teachers address these experiences by asking questions and offering alternative perspectives and suggestions for practice. Critical incidents are considered powerful tools to make tacit beliefs and values explicit, especially when they are discussed collaboratively (Tripp, 1993). The peer meetings lasted approximately 45 minutes. The teacher trainer intervened as little as possible to stimulate natural interaction processes. The meetings were videotaped and transcribed.

\section{ANALYSIS}

Data analysis consisted of three steps:

1. The videotapes were analysed in three phases to identify the types of interactions. First, all procedural interactions were removed to obtain a list of task-related interactions. Second, the first author used a top down strategy to categorise the task-related interactions (Miles and Huberman, 1994) in accordance with the interaction types developed by Meijer (2005). Third, the initial labelling was discussed by the first and third authors to validate the initial analysis. Illustrative examples of the different types of interactions were selected.

2. The scope of the reflection processes in terms of the teaching dimensions addressed was analysed by labelling the interactions in accordance with Kelchtermans and Hamiltons' (2004) framework. This was done by the first author and discussed with the third author. 
Table I. Format of the critical incident method (Hendriksen, 1997)

\begin{tabular}{|c|c|}
\hline Phase & Clarification \\
\hline $\begin{array}{l}\text { All the critical incident } \\
\text { descriptions are read. }\end{array}$ & $\begin{array}{l}\text { All the participating teachers submit an account } \\
\text { of a critical incident. }\end{array}$ \\
\hline One critical incident is selected. & $\begin{array}{l}\text { One critical incident is selected for discussion } \\
\text { and analysis. }\end{array}$ \\
\hline The critical incident is clarified. & Clarification of the critical situation. \\
\hline $\begin{array}{l}\text { Clarifying questions are } \\
\text { prepared during a short break. }\end{array}$ & $\begin{array}{l}\text { Questions must only ask for clarification; no } \\
\text { solutions or alternatives are to be implied or } \\
\text { suggested. }\end{array}$ \\
\hline Question round & $\begin{array}{l}\text { All clarifying questions are put to the presenter } \\
\text { of the critical incident; he or she answers the } \\
\text { questions. }\end{array}$ \\
\hline $\begin{array}{l}\text { Analysis and advice are } \\
\text { prepared during a short break. }\end{array}$ & $\begin{array}{l}\text { Alternative approaches or different perspectives on } \\
\text { the situation are suggested. }\end{array}$ \\
\hline Round of advice & Advice is given as well as points for analysis. \\
\hline $\begin{array}{l}\text { Plenary discussion about } \\
\text { analysis and advice. }\end{array}$ & $\begin{array}{l}\text { The pros and cons of the advice and analysis are } \\
\text { discussed. }\end{array}$ \\
\hline $\begin{array}{l}\text { Reaction by the presenter } \\
\text { of the critical incident. }\end{array}$ & $\begin{array}{l}\text { The presenter selects the alternative suggestion and } \\
\text { the analysis that best fit the situation. }\end{array}$ \\
\hline Evaluation round & $\begin{array}{l}\text { The participants indicate what they have learned } \\
\text { from the discussion. }\end{array}$ \\
\hline
\end{tabular}

3. The relationship between the types of interaction and the scope of the collaborative reflections was analysed by identifying moments in the discussion where the collaborative reflection broadened. The first author summarised the data by selecting fragments in which a new teaching dimension was introduced, and investigated which types of interactions were important for the introduction of a new teaching dimension. Finally, the first and third authors discussed the summaries and selections to enhance the quality of the analysis.

\section{Results}

\section{TYPES OF INTERACTIONS}

The classification of the interaction types was found to fit the data. The categories could be linked to the different phases of the Incident method, although the phases did not always occur in the proposed order. For example, after the advice round, new follow-up questions were occasionally asked and interpretations made. Table II presents an overview of the 
Table II. Types of interactions (based on Meijer, 2005) and illustrative examples from the data collected at Maastricht Medical School

\begin{tabular}{|c|c|c|}
\hline $\begin{array}{l}\text { Phase } \\
\text { (interaction types) }\end{array}$ & Description & Illustrative example \\
\hline \multicolumn{3}{|c|}{ Clarification of the critical incident } \\
\hline Initiating / statement $(I / S)$ & $\begin{array}{l}\text { Initial description of } \\
\text { the situation and/or } \\
\text { discussion of the } \\
\text { potentially problematic } \\
\text { character of the situation. }\end{array}$ & $\begin{array}{l}\text { "One of the things } \\
\text { that I find really } \\
\text { irritating (...)." } \\
\text { "So, in a nutshell, that's } \\
\text { the story." }\end{array}$ \\
\hline \multicolumn{3}{|l|}{ Question round } \\
\hline Follow-up questioning ( $F Q$ ) & $\begin{array}{l}\text { Request for further } \\
\text { description of certain } \\
\text { aspects of the situation } \\
\text { or information on other } \\
\text { aspects of the situation. }\end{array}$ & $\begin{array}{l}\text { "What do you expect } \\
\text { of a group of students } \\
\text { attending your lecture?" }\end{array}$ \\
\hline Clarifying situation (ClfS) & $\begin{array}{l}\text { Additional details and/or } \\
\text { clarification of the situation. }\end{array}$ & $\begin{array}{l}\text { "That they make an } \\
\text { effort to listen when } \\
\text { someone is standing } \\
\text { before them (...) that's } \\
\text { what I expect from } \\
\text { students, professional } \\
\text { behaviour." }\end{array}$ \\
\hline Interpreting situation (IntS) & $\begin{array}{l}\text { Description of the } \\
\text { significance of the } \\
\text { situation for one or } \\
\text { more of the individuals } \\
\text { involved and/or the } \\
\text { consequences of the } \\
\text { situation. }\end{array}$ & $\begin{array}{l}\text { "Hm, and that } \\
\text { actually happened, } \\
\text { despite all the chaos." }\end{array}$ \\
\hline Judging a situation (JS) & $\begin{array}{l}\text { Statement of opinion about } \\
\text { a situation (but NOT about } \\
\text { one's behaviour in that } \\
\text { situation). }\end{array}$ & $\begin{array}{l}\text { "Yes, well, this is } \\
\text { unacceptable." }\end{array}$ \\
\hline Explaining (Expl) & $\begin{array}{l}\text { Provision of reasons for a } \\
\text { situation to be problematic } \\
\text { or arguments for a } \\
\text { particular approach. }\end{array}$ & $\begin{array}{l}\text { "Yes, that's one of the } \\
\text { tricks, when they get restless, } \\
\text { you lower your voice } \\
\text { so that those who are } \\
\text { motivated to listen cannot } \\
\text { hear you either and they } \\
\text { will call the } \\
\text { others to order." }\end{array}$ \\
\hline
\end{tabular}


Table II. Continued

\begin{tabular}{|c|c|c|}
\hline $\begin{array}{l}\text { Phase } \\
\text { (interaction types) }\end{array}$ & Description & Illustrative example \\
\hline Summarising (Sum) & $\begin{array}{l}\text { Briefly recalling aspects } \\
\text { of the situation and/or } \\
\text { briefly recalling } \\
\text { conversation or part } \\
\text { of the conversation. }\end{array}$ & $\begin{array}{l}\text { "My advice is generally in line } \\
\text { with the questions I just asked you. } \\
\text { You have certain expectations. } \\
\text { Unfortunately, those expectations } \\
\text { do not match the currently } \\
\text { prevailing attitude among students. } \\
\text { Well, that causes a lot of emotion, } \\
\text { doesn't it, anger, frustration (...)" }\end{array}$ \\
\hline Concretising (Concr) & $\begin{array}{l}\text { Elaboration of the } \\
\text { situation or certain } \\
\text { aspects of the situation } \\
\text { by giving examples. }\end{array}$ & $\begin{array}{l}\text { "Well, when I go to the theatre } \\
\text { I am silent during the } \\
\text { performance. An actor or } \\
\text { musician expects me to remain } \\
\text { seated and keep my mouth shut. } \\
\text { And I really expect the students } \\
\text { to do the same." }\end{array}$ \\
\hline $\begin{array}{l}\text { Guiding/directing } \\
\text { (Guid/D) }\end{array}$ & $\begin{array}{l}\text { The posing of questions or } \\
\text { remarks aimed to guide the } \\
\text { discussion in a specific } \\
\text { direction, prompt a specific } \\
\text { line of thinking, or elicit a } \\
\text { specific solution. }\end{array}$ & $\begin{array}{l}\text { "Perhaps it might be interesting } \\
\text { to pursue this a bit more. B said, } \\
\text { I think those students are angry. } \\
\text { How do you think the students feel? } \\
\text { How does it make them feel to sit } \\
\text { there while this is going on?" }\end{array}$ \\
\hline $\begin{array}{l}\text { Giving information } \\
\text { (FactI) }\end{array}$ & $\begin{array}{l}\text { The provision of factual } \\
\text { information. }\end{array}$ & $\begin{array}{l}\text { "In the morning they studied a case } \\
\text { and in the afternoon they attended a } \\
\text { lecture by a content expert." }\end{array}$ \\
\hline \multicolumn{3}{|l|}{ Advice round } \\
\hline $\begin{array}{l}\text { Proposing an } \\
\text { alternative (PrpA) }\end{array}$ & $\begin{array}{l}\text { The proposal or description } \\
\text { of an alternative approach } \\
\text { to the situation or } \\
\text { alternative manner of } \\
\text { working within } \\
\text { the situation. }\end{array}$ & $\begin{array}{l}\text { "You could also say: I'm } \\
\text { getting angry, and I will } \\
\text { give the students a good } \\
\text { talking to, or I will leave } \\
\text { the room." }\end{array}$ \\
\hline Advising $(A d v)$ & $\begin{array}{l}\text { Provision of advice with } \\
\text { regard to manners of } \\
\text { working, behaviour, } \\
\text { position within school, } \\
\text { and so forth. }\end{array}$ & $\begin{array}{l}\text { "So my advice would be } \\
\text { to just make it clear to } \\
\text { them that you will not } \\
\text { tolerate this." }\end{array}$ \\
\hline
\end{tabular}


Table II. Continued

\begin{tabular}{|c|c|c|}
\hline $\begin{array}{l}\text { Phase } \\
\text { (interaction types) }\end{array}$ & Description & Illustrative example \\
\hline \multicolumn{3}{|l|}{$\begin{array}{l}\text { Plenary discussion on } \\
\text { submitted analyses and advice }\end{array}$} \\
\hline $\begin{array}{l}\text { Reacting to alternative } \\
\text { (pos / neg) (ReactA) }\end{array}$ & $\begin{array}{l}\text { The provision of a } \\
\text { reaction to an } \\
\text { approach or manner } \\
\text { of working (positive } \\
\text { or negative). }\end{array}$ & $\begin{array}{l}\text { "No. As I said just now: } \\
\text { I'm not the kind of person } \\
\text { to run away with my tail } \\
\text { between my legs." }\end{array}$ \\
\hline Exploring alternative (ExplA) & $\begin{array}{l}\text { Description or } \\
\text { elaboration of the } \\
\text { content or } \\
\text { consequences } \\
\text { of an alternative. }\end{array}$ & $\begin{array}{l}\text { "When I hear you interpret } \\
\text { it this way, I immediately } \\
\text { think we should try and } \\
\text { together work out how } \\
\text { we can get to a situation } \\
\text { where information is } \\
\text { maximised, keeping the } \\
\text { channels of communication } \\
\text { open." }\end{array}$ \\
\hline \multicolumn{3}{|l|}{$\begin{array}{l}\text { Response of the } \\
\text { presenter of the critical incident }\end{array}$} \\
\hline $\begin{array}{l}\text { Selecting/agreeing on solution } \\
\text { (SelectA) }\end{array}$ & $\begin{array}{l}\text { Select a solution } \\
\text { from available } \\
\text { alternatives and } \\
\text { agree on the best } \\
\text { way to deal with } \\
\text { the } \\
\text { situation. }\end{array}$ & $\begin{array}{l}\text { "I think that agreeing on } \\
\text { rules is a brilliant idea } \\
\text { actually." }\end{array}$ \\
\hline Judging an alternative ( $J A)$ & $\begin{array}{l}\text { Appraisal of an } \\
\text { alternative or its } \\
\text { consequences. }\end{array}$ & $\begin{array}{l}\text { "The first thing you say, } \\
\text { and I think that is a much } \\
\text { better strategy, is that the } \\
\text { students play by different } \\
\text { rules than I do, when you } \\
\text { say we'll make rules together } \\
\text { and agree on them." }\end{array}$ \\
\hline
\end{tabular}

interaction types with examples from the data. Interestingly, 'guiding' was mostly performed by the teacher trainer, who asked questions or made remarks that subtly directed the teachers towards a certain way of thinking or a specific solution that had been mentioned earlier but had not been paid much attention to (example of 'guiding' in Table II). 


\section{SCOPE OF COLLABORATIVE REFLECTIONS}

Although at the end of the peer meetings advice was given about performance, which represented the technical-instrumental dimension, the other teaching dimensions were also addressed during the discussions. Table III shows how content was assigned to different dimensions. We also present illustrative quotes for each dimension.

\section{THE RELATIONSHIP BETWEEN TYPES OF INTERACTION AND SCOPE OF REFLECTION}

We found that during the interactions in the group the discussion broadened to cover a wider range of teaching dimensions. After selecting fragments in which a new teaching dimension was introduced, we discovered that two types of interactions were crucial for broadening the collaborative reflection process: 'guiding/directing', and 'proposing an alternative', and 'exploring an alternative'. On closer inspection of the data, we found that these interaction types could be split up into those focused on action (by guiding/directing towards a specific solution or proposing an alternative strategy) and those focused on thought (by guiding/directing towards a specific way of thinking

Table III. Teaching dimensions (based on Kelchtermans and Hamilton, 2004) and illustrative quotes from the Maastricht Medical School peer data

\begin{tabular}{|c|c|c|}
\hline Dimension & Description & Illustrative example \\
\hline Technical-instrumental (T) & $\begin{array}{l}\text { 'How questions'; } \\
\text { strategies, tricks, etc. }\end{array}$ & $\begin{array}{l}\text { "Yes, you can just agree on rules, } \\
\text { such as, when things get out of hand, } \\
\text { this will be the consequence." }\end{array}$ \\
\hline Moral (M) & $\begin{array}{l}\text { Beliefs about good } \\
\text { teaching, expectations, } \\
\text { rules and codes, norms } \\
\text { and values, } \\
\text { professional identity. }\end{array}$ & $\begin{array}{l}\text { "I expect the students to make an } \\
\text { effort to be silent and listen when } \\
\text { someone is giving a lecture. } \\
\text { And that they just leave when } \\
\text { they're not interested." }\end{array}$ \\
\hline Political (P) & $\begin{array}{l}\text { Relation to others: } \\
\text { power, responsibilities, } \\
\text { interests, loyalty. }\end{array}$ & $\begin{array}{l}\text { "Who determines what is good? } \\
\text { Well, so you have a certain level of } \\
\text { ambition, and who is going to say } \\
\text { what is good? Is your } \\
\text { level the right one?" }\end{array}$ \\
\hline Emotional (E) & $\begin{array}{l}\text { Feelings, passion, } \\
\text { frustration, ideals. }\end{array}$ & $\begin{array}{l}\text { "You talk about being angry. } \\
\text { So there is a whole lot of } \\
\text { emotion there. And my first } \\
\text { question is: why does this } \\
\text { feeling emerge?" }\end{array}$ \\
\hline
\end{tabular}


or proposing a different approach to the problem situation). The following two discussion fragments illustrate the importance of these interaction types for broadening the discussion. The Appendix contains case descriptions with discussion summaries to provide context information.

In case I (Appendix I) a teacher expresses frustration about students' disruptive behaviour during his lecture. First the moral dimension was addressed by guiding and proposing an alternative and subsequently the emotional, technical-instrumental, and political dimensions were addressed as well. Discussion fragment I (Table IV) shows how one of the teachers proposes an alternative and guides/directs the teacher who presented the incident $(Z)$ towards a different view on students' and teachers' roles, which was explored: $Z$ expects the students to show respect for their teacher, i.e. pay attention to what he or she has to say. $Z$ proposes to use tricks to secure the students' attention. Another way for teachers to capture students' attention is when students are eager to hear what the teacher has to say, i.e. because they actually want to use the teacher as a valuable source of information. This fragment shows that by proposing and exploring an alternative and guiding / directing the discussion, one can move back from the technical-instrumental and political dimension to two specific aspects of the moral dimension: views of good teaching and the teacher's professional role.

In Case II (Appendix II) teacher B describes his irritation and frustration due to teachers' lack of cooperation with a curriculum innovation project. The discussion starts in a rather technical way by proposals of alternatives. Discussion fragment II (Table V) illustrates how the political dimension is addressed by guiding/directing and proposing and exploring an alternative: 'If you allow others to learn from their mistakes, how bad is the damage going to be; are you to blame when things go wrong?' The discussion continues by focusing on what it would mean for B if the innovation would fail. One of the teachers guides/directs B towards his emotions by proposing an alternative: is he afraid that the innovation will fail, and will he look upon this as a personal failure? This fragment shows that, by guiding/directing and proposing and exploring an alternative, the discussion turns to the political dimension and finally by guiding/ directing back to the emotional dimension by further analysing B's feelings about the proposed alternative.

\section{Conclusion and discussion}

The aim of this study was to explore the relationship between medical teachers' interactions during peer meetings and the scope of their collaborative reflection processes. We took Meijer's (2005) category system as the point of departure for identifying types of interactions. The interaction types could be related to the phases in the Incident Method, which was used to 
Table IV. Coded discussion fragment I

Interaction type Dimension

A: (...) I think that you not only want the Guid/D PrpA Moral students to respect you, you also need their attention and to me those are different things. And when you start looking at how to gain their respect, just by tricks and by saying I will not tolerate this, let's make some rules, this is what we're going to do, but when you start looking at getting the students' attention, you should really work differently, with interaction and I go along with what $\mathrm{H}$ just said, who is at the centre?

Actually, you already know what you know, you Guid/D have your story, your knowledge and experience. But you want to transmit it to the students. And you may try and force it on them and that was why I said, well, you can take a horse to the water but you cannot make it drink.

So, you can offer them all sorts of things, but when they just won't accept it from you and that is not so much to do with respect as with capturing their attention. You should challenge them so that they listen to you not just because they are being polite, but because they actually want to hear what you have to say. To me that's something entirely different.

Z: Well, I do have an idea about that. Look, we have, we

ReactA offer students a certain programme, a package which we believe they must have mastered when they have become doctors. That's the real objective.

The programme, all our efforts, they are all focused on giving the students the baggage they need when they are doctors.

Students choose to do this, they get a substantial amount of government money so to speak every year to do this and I think in return they might show some respect and interest.

$\mathrm{T}$ : Yes, well, but she is saying something else.

A: Yes, only what I am trying to say is that Guid/D however much you may be telling them, what they will take home with them is something entirely different. 


\begin{tabular}{|c|c|c|c|}
\hline & & Interaction type & Dimension \\
\hline $\mathrm{Z}:$ & No, I know that, it's really marginal. & ReactA & Moral \\
\hline A: & $\begin{array}{l}\text { And it's not about getting students to be quiet } \\
\text { so that you can say what you have to say, but to } \\
\text { get them motivated in such a way that they } \\
\text { actually want to hear what you have to say. } \\
\text { And to me, those are two very different things. }\end{array}$ & Guid/D & \\
\hline B: & $\begin{array}{l}\text { Yes, when I hear you interpret it like this (A), then } \\
\text { I immediately think, but I don't think that's } \\
\text { what you (Z) really mean, it's about getting } \\
\text { information to the students. And you (Z) think } \\
\text { that you'll achieve the most with a sort of } \\
\text { confrontation model, that's not what you really } \\
\text { mean, but that's how it comes across; I have } \\
\text { something to say, this is it and you have to } \\
\text { take it home with you, I am exaggerating now, } \\
\text { and you're even getting paid for it, while I hear } \\
\text { A saying, yes, but you have to try and find a } \\
\text { different form, not confrontation, but more } \\
\text { collaboration, we have to work together to find a } \\
\text { form in which information can be optimised, } \\
\text { where the channels are kept open. }\end{array}$ & ExplA & \\
\hline A: & $\begin{array}{l}\text { I would even turn it around altogether, } \\
\text { I am the information source and the students } \\
\text { should make the most of that. }\end{array}$ & Guid/D & \\
\hline B: & $\begin{array}{l}\text { Yes, you would like them to soak it all up, } \\
\text { that would be even better. }\end{array}$ & ExplA & \\
\hline
\end{tabular}

structure the discussion, although the phases did not always occur in the proposed order. All peer meetings ended with the technical-instrumental dimension consisting of advice about performance. This might be inherent in the Critical Incident Method and its focus on the identification of alternative solutions (Hendriksen, 1997). However, before arriving at the advice, the group addressed the other teaching dimensions as well (Kelchtermans and Hamilton's, 2004) in analysing the teaching situations. We can conclude that teachers' interactions promoted not only reflections on technical-instrumental questions ('how to'), but also on normative, political and emotional issues, thus covering the full scope of Kelchtermans and Hamilton's (2004) 
Table V. Coded discussion fragment II

\begin{tabular}{|c|c|c|c|}
\hline & & Interaction type & Dimension \\
\hline A: & $\begin{array}{l}\text { I wonder what will go wrong when they } \\
\text { don't do it? How serious is the damage, } \\
\text { can you repair it, well, might it be sensible } \\
\text { to let the department make their own mistakes? } \\
\text { Who's going to suffer? Well, does it backfire on } \\
\text { you or is it shifted to someone else? }\end{array}$ & Guid/D PrpA & Political \\
\hline B: & No, eh. & $\mathrm{XX}$ & \\
\hline A: & $\begin{array}{l}\text { Yes, I was thinking like, in some situations, } \\
\text { yes, when you allow a student to make an error } \\
\text { with medication and the patient dies, that } \\
\text { would be rather careless. But in other situations } \\
\text { where people can make their own mistakes and } \\
\text { maybe they will not take the best option, but they } \\
\text { will learn that next time they should do things } \\
\text { differently, then it may be better to ... }\end{array}$ & Guid/D ExplA & \\
\hline B: & $\begin{array}{l}\text { In that case, yes that would be best, the latter one, } \\
\text { yes that's definitely true. }\end{array}$ & ReactA & \\
\hline A: & $\begin{array}{l}\text { To let him make his own mistakes, yes so that's } \\
\text { also considering, well, how serious, how grave is it, } \\
\text { what can go wrong, I cannot really judge that. }\end{array}$ & ExplA & \\
\hline B: & $\begin{array}{l}\text { I agree with you that it's better to allow people } \\
\text { to make their own mistakes and then, in an ideal } \\
\text { world, that would mean they would not do it again. } \\
\text { Only I do not really buy this ideal world. } \\
\text { In this case, this very concrete case, I think, well, } \\
\text { yes it is a serious problem because when somebody } \\
\text { finds out, the department finds out that things are } \\
\text { going wrong that in an affiliated hospital things } \\
\text { are not being done as they should be to enable } \\
\text { appropriate assessment of a clerkship, then, well } \\
\text { there are already students there, eh yes, they are } \\
\text { there and usually you cannot reverse processes very } \\
\text { quickly, just like that, from one day to the next, } \\
\text { that requires investment, also in teachers. That } \\
\text { requires a culture change when you expect different } \\
\text { things of teachers. And in my work I often deal with } \\
\text { matters where you have to make an investment } \\
\text { first and where you have to bring about culture } \\
\text { change, especially in the details. }\end{array}$ & ReactA & \\
\hline
\end{tabular}


$\mathrm{Z}$ : But what can possibly go wrong?

Guid/D ExplA

Just tell me, is it assessment in particular and all the paperwork that is not going to be filled out correctly?

B: Yes, or that they altogether don't, yes very ExplA concretely in this case that they don't know they are supposed to observe students, that they don't know they are supposed to mark reports, what it is they are supposed to observe, what a navigation plan is, that's one of those crazy Maastricht ideas isn't it, how are they all connected and why on earth are we doing it in the first place. Those are important things for teachers, to motivate the teachers.

$\mathrm{T}$ : With serious consequences ExplA

B: With consequences for the students, yes, which means ExplA the new curriculum gets the blame of course, (laughs), not the teachers, and so also those who advocate it, so also I, so it backfires on me rather than on $t$ he teachers.

Z: So you're actually afraid that the new curriculum will fail, aren't you? Is that what you're thinking?

B: No, well, actually, in this concrete case, I think that this department is just not doing enough for the affiliation in relation to the new curriculum.

$\mathrm{H}$ : But, to return to A's questions, you're afraid that it will backfire on you in two ways: one, that the new curriculum is seen to fail for instance and you are thinking I have contributed to that and I'm going to be blamed when things go wrong while actually it's not my fault but other people's. And the second point like, well, that you yourself are going to feel like a failure.

B: Yes, eh, yes, yes

Emotional

$\mathrm{H}$ : For, because you are part of it, you will get the blame as one of the builders.

B: Yes, yes as one of the builders yes (...) that's right 
teaching dimensions. Three interaction types appeared to be important for bringing new elements into the discussion: 'guiding/directing', 'proposing an alternative', and 'exploring an alternative'. These interaction types address different viewpoints by directing attention to and suggesting different ways of acting and different ways of thinking. Stimulating different ways of thinking by looking at beliefs and values that usually remain implicit is important to arrive at a better understanding of teaching and stimulate improvement (Gilroy, 1993; Eraut, 1994). Accordingly, we might suppose that the technical advice given to the teachers during the peer sessions was based on a deeper understanding of their practice as a result of the collaborative reflections. This is in line with suggestions from the literature that social interactions promote reflection and the sharing of ideas and thereby help professionals improve and refine their functioning (Ackland, 1991; Joyce and Showers, 1995; Gallacher, 1997; Thijs and Van den Berg, 2002). However, it was interesting to see the teacher trainer playing a prominent role by 'guiding' and subtly directing the teachers towards a certain way of thinking or a solution that was mentioned earlier but largely ignored. This might imply that the teacher trainer has an essential role in adding value to teachers' interactions and collaborative reflections by stimulating consideration of new insights and fostering gains in understanding.

It is striking that despite the use of a formal model, like the Incident Method, which has been critiqued for guiding teachers towards an exclusive focus on technical reflection (Kelchtermans and Hamilton, 2004), teachers' collaborative reflections covered the broad range of teaching dimensions. However, the fact that the stages were not always followed in a strict order may have been very important for widening the scope of the reflections.

This study has some limitations. First, the participants were all experienced teachers, who engaged in professional development with a career in teaching in mind. This suggests that they were strongly motivated to reflect collaboratively and probably had above average reflective and peer coaching skills. Consequently, the results cannot simply be generalised to other, perhaps not as highly motivated, groups of teachers. Second, the study provides indications for changes in teachers' beliefs and attitudes, for example those of teacher $\mathrm{Z}$ in case I. However, this was not directly measured and neither were the effects of these changes on teaching practice.

Some guidelines for practice can be extracted from this study. First, since the technical advice given to the teachers appears to be based on a deeper understanding of teaching practice gained from collaborative reflection with peers, peer meetings seem to be a promising method for promoting teachers' learning and development and thus for improving the quality of teaching. Making official room for peer meetings is an essential starting point in this respect. Therefore, greater frequency of peer meetings for health sciences 
teachers is to be recommended. Second, the use of formal models of interacting and reflecting appears to be valuable provided the models are applied flexibly. Third, the study provides a basis for teacher trainers in health sciences faculties to recognise different kinds of interactions and levels of reflection which might help them structure and guide peer meetings for teachers and train teachers to interact in a fruitful manner. Finally, it might be useful to introduce teachers to Kelchtermans and Hamilton's model when teaching situations are being analysed.

In future research, with larger data sets, subcategories for the teaching dimensions might be developed. Furthermore, because the ultimate purpose of reflecting and meeting with colleagues is to promote teachers' professional development and improve teaching practice, interviews, questionnaires and teaching observations should be collected to appraise the longer term impact on teachers' learning and teaching practice.

\section{Acknowledgements}

The authors wish to thank the teachers for their active and constructive participation in the study, and Science Vision for videotaping the peer meetings. Funding: This research was funded by the Netherlands Organisation for Scientific Research (NWO), Project number 411-21-202.

\section{Appendix I}

CAse I: A disturbed lecture

SHORT DESCRIPTION OF THE CRITICAL INCIDENT

Teacher $\mathrm{Z}$ arrives late for a lecture he has to give, the equipment doesn't work, the students get restless and noisy, and the lecture proceeds rather chaotically. The teacher tries to remain calm and finishes the lecture but feels very frustrated when he leaves, because the students did not show him proper respect (emotional and moral dimension).

\section{DISCUSSION SUMMARY}

First some follow-up questions are asked about Z's expectations of the students (moral dimension). Next, Z's attention is drawn to the students' emotions: he was not the only one who was angry, the students were angry too (emotional dimension). $\mathrm{Z}$ is asked why he got angry and why he decided to finish the lecture despite the turmoil instead of just leaving. (here a new dimension is introduced when an alternative is proposed: the 
technical-instrumental dimension). Finally, $\mathrm{Z}$ is asked if he has encountered similar situations before. In the advice round, $Z$ is advised to show his emotions to the students and discuss his expectations with them. Furthermore, $\mathrm{Z}$ is advised to expect and accept the possibility that the students may not behave as he expects them to. $Z$ responds by saying that disturbance is not to be tolerated. It is suggested that he should indicate ground rules for lectures. However, is it $\mathrm{Z}$ who should decide about these rules? This is a rather hierarchical view of the teacher-student relationship (here the political dimension is addressed by guiding/directing). One of the other teachers confronts $\mathrm{Z}$ with a different view of students' and teachers' roles: $\mathrm{Z}$ expects students to show respect for their teachers and he wants to achieve this by using tricks. However, teachers can also capture students' attention when students are eager to hear what the teacher has to say, because they actually want to use the teacher as a source of information (here, by guiding/directing, and proposing and exploring an alternative the discussion moves back from the technical-instrumental and political dimension to two specific aspects of the moral dimension: views of good teaching and the teacher's professional role; see discussion fragment I). The discussion continues and the function of lectures is addressed. $\mathrm{Z}$ is also advised to ask for help with his professional development to reconsider his views of good teaching as well as his role as a teacher. Finally, $\mathrm{Z}$ evaluates the advice given to him. He accepts the advice to seek help with his professional development and he expresses appreciation for the technical advice.

\section{Appendix II}

\section{CASE II: IRRITATION AND FRUSTRATION ABOUT AN INNOVATION PROJECT} SHORT DESCRIPTION OF THE CRITICAL INCIDENT

Teacher $\mathrm{B}$ is in charge of a curriculum innovation project and becomes irritated and frustrated when other persons involved in the curriculum want to implement changes less rapidly and give higher priority to other matters (emotional dimension, moral dimension).

\section{DISCUSSION SUMMARY}

An alternative is proposed and explored, i.e. releasing irritations and frustrations (technical-instrumental dimension). B explains that he has difficulty expressing his frustration and irritation in other situations as well. Instead of letting things take their course, he usually tries to convince the other persons involved that the innovations are really very important and must be implemented. B is asked: if you allow other people to learn from their mistakes, how bad will the damage be? Are you to blame when things go wrong? (Here, by guiding/directing and proposing an alternative, the political dimension is 
addressed, discussion fragment II). After exploration of the alternative the discussion continues and focuses on what failure of the innovation project would mean to B. B is asked if he is afraid that the innovation will fail, and that he will regard this as a personal failure (Here, by guiding/directing, the discussion again turns from the political dimension to the emotional dimension by further analysis of how B feels about the proposed alternative, Discussion fragment II). B is asked if he understands why others might do things differently than he expects them to. $\mathrm{B}$ reacts by saying that they may have other priorities and that he sees it as his task to change these (Here, by guiding/directing the moral dimension is addressed again). In the advice round, B is advised to come to an accommodation with those involved in the innovations and accept that innovation processes take time. A course in management of organisational change might be helpful. Furthermore, B is advised to consider how he interprets his responsibilities and why he should have such a deeply felt need to be in control. B is advised to give others a chance to learn from their mistakes and leave the responsibility with them. Finally, B is advised to seek other interests he can enjoy to counterbalance his feelings of irritation and frustration. B evaluates the advice and says that he realises that innovation processes take time and commitment and that it is important to reach accommodations with others. When the teacher trainer asks B what he sees as his greatest challenge, he says that he would like to discover why it is so difficult for him to let go.

\section{References}

Ackland, R. (1991). A review of the peer coaching literature. Journal of Staff Development 12: 22-27.

Bereiter, C. (2002). Education and mind in the knowledge society Mahwah NJ: Lawrence Erlbaum Associates.

D’Eon, M., Overgaard, V. \& Rutledge Harding, S. (2000). Teaching as a social practice: implications for faculty development. Advances in Health Sciences Education 5: 151-162.

Eraut, M. (1994). Developing professional knowledge and competence London: Falmer Press.

Fisher, F., Bruhn, J, Gräsel, C. \& Mandl, H. (2002). Fostering collaborative knowledge construction with visual tools. Learning \& Instruction 12: 213-232.

Gallacher, K. (1997). Supervision, mentoring and coaching. In: P.J. Winton, J.A. McCollum \& C. Catlett (eds.), Reforming personnel preparation in early intervention. Issues, models, and practical strategies, pp. 191-214. Baltimore Maryland: Paul H. Brooks Publishing Co.

Gilroy, P. (1993). Reflections on Schön, an epistemological critique. In: P. Gilroy \& M. Smith (eds.), International analysis of teacher education, London: Falmer Press.

Hatton, N. \& Smith, D (1995). Reflection in teacher education: Towards a definition and implementation. Teaching \& Teacher Education 11(1): 33-49.

Hendriksen, J. (1997). Begeleid intervisiemodel, collegiale advisering en probleemoplossing. [Guided peer model, advising colleagues and problem solving]. Baarn, Nelissen.

Joyce, C. \& Showers, B. (1995). Student achievement through staff development: fundamentals of school renewal New York: Longman.

Jung, B., Tryssenaar, J. \& Wilkins, S. (2005). Becoming a tutor: exploring the learning experiences and needs of novice tutors in a PBL programme. Medical Teacher. 27(7): 606-612. 
Kelchtermans, G. \& Hamilton, M.L. (2004). The dialectics of passion and theory: exploring the relationship between self-study and emotion. In: J.J. Loughran, M.L. Hamilton, V. Kubler LaBoskey \& T. Russell (eds.), International handbook of self-study of teaching and teacher education practices, pp. 785-810. Dordrecht, the Netherlands: Kluwer Academic Publishers.

Koning, A. (1995). In gesprek met de leerling. [Conversations with students]. Houten: Educatieve Partners/ KPC.

Korthagen, F.A.J. (2001). Linking practice and theory: The pedagogy of realistic teacher education. Mahwah NJ: Lawrence Erlbaum Associates, Inc.

Korthagen, F.A.J., Koster, B., Melief, K., \& Tigchelaar, A. (2002). Docenten leren reflecteren. [Learning teachers to reflect]. Soest, Nelissen.

Korthagen, F.A.J. (2004). In search of the essence of a good teacher: towards a more holistic approach in teacher education. Teaching and Teacher Education 20: 77-97.

MacDougall, J. \& Drummons, M.J. (2005). The development of medical teachers: an inquiry into the learning histories of 10 experienced medical teachers. Medical Education 39: 1213-1220.

Meijer, P.C. (2005). Tracing learning in Intervision. Paper presented at the 32nd Dutch-Flemish Educational Research Days (ORD), Gent, Belgium.

Miles, M.B. \& Huberman, A.M. (1994). Qualitative data analysis London: Sage.

Palmer, P.J. (1998). The courage to teach San Francisco: Jossey-Bass.

Thijs, A. \& Van den Berg, E. (2002). Peer coaching as part of a professional development program for science teachers in Botswana. International Journal of Educational Development 22: 55-68.

Tripp, D. (1993). Critical incidents in teaching London: Routledge. 